\title{
FORMULATION AND PROCESS OPTIMIZATION OF MUFFIN PRODUCED FROM COMPOSITE FLOUR OF CORN, WHEAT AND SWEET POTATO
}

\author{
[Formulasi dan Optimasi Proses Produksi Mufin dari Tepung Komposit Jagung, Gandum dan Ubi Jalar]
Eko Hari Purnomo ${ }^{1,2)^{*}}$, Azis B. Sitanggang ${ }^{1,2)}$, Denny S. Agustin ${ }^{2)}$, Purwiyatno Hariyadi1,2) and Stefani Hartono1) \\ 1) Department of Food Science and Technology, Faculty of Agricultural Engineering and Technology, \\ Bogor Agricultural University, Bogor \\ 2) South East Asian Food and Agricultural Science and Technology (SEAFAST) Center, Bogor Agricultural University, Bogor
}

Submitted November $02^{\text {th }} 2012$ / Accepted December $06^{\text {th }} 2012$

\begin{abstract}
Intensification of use of local carbohydrate sources such as corn and sweet potato is expected to minimize wheat import and support food diversification program. The objective of this research was to optimize the composite flour composition and baking process conditions in muffin production. This research was divided into 3 steps namely formula optimization using mixture design techniques, process optimization using response surface methodology and final product analysis. The formula and process optimization was based on sensory parameter using hedonic rating test involving 70 untrained panelists. The results showed that the optimum formula was a formula with $4 \%$ wheat flour, $86 \%$ corn flour, and $10 \%$ sweet potato flour. The optimum baking condition was 39 minutes at $157^{\circ} \mathrm{C}$. Analysis of muffin made with the optimum formula and baking conditions showed that the muffin had hardness, moisture, ash, protein, fat, cabohydrate, and crude fibre of $107.3 \mathrm{gf}, 23.22 \%, 1.83 \%, 5.89 \%$, $22.46 \%, 69.82 \%$, and $0.26 \%$, respectively.
\end{abstract}

Keywords: composite flour, corn flour, muffin, sweet potato flour

\begin{abstract}
ABSTRAK
Intensifikasi penggunaan sumber karbohidrat lokal, misalnya jagung dan ubi jalar, diharapkan mampu menurunkan impor gandum dalam rangka mendukung program diversifikasi pangan. Tujuan dari penelitian ini adalah untuk mengoptimasi komposisi tepung komposit dan kondisi pemanggangan dalam pembuatan mufin. Penelitian terdiri dari 3 tahap utama yaitu optimasi formula menggunakan teknik mixture design, optimasi proses pemanggangan menggunakan response surface methodology, dan analisis produk akhir. Optimasi formula dan proses pemanggangan didasarkan pada parameter sensori yang diperoleh dari uji hedonik dengan menggunakan 70 panelis tidak terlatih. Hasil yang diperoleh menunjukkan bahwa formula tepung komposit yang optimum adalah 4\% tepung terigu, $86 \%$ tepung jagung, and $10 \%$ tepung ubi jalar. Kondisi optimum pemanggangan adalah pada suhu $157^{\circ} \mathrm{C}$ selama 39 menit. Analisis produk akhir menunjukkan bahwa mufin dari tepung komposit secara berurutan memiliki kekerasan, kadar abu, protein, lemak, karbohidrat, dan serat kasar sebesar 107,3 gf, 23,22\%, 1,83\%, 5,89\%, 22,46\%, 69,82\%, dan $0,26 \%$.
\end{abstract}

Kata kunci: komposit tepung, tepung jagung, mufin, tepung ubi jalar

\section{INTRODUCTION}

The dependency of Indonesia on import of wheat flour is historically originated from diversification of carbohydrate source during Green Revolution in 1970. Over the past four decades, there was a shift in culture which leads to the higher consumption of wheat, in the form of wheat flour-based products such as noodles and bread, than corn or tubers. Based on data from the Association of Indonesian Wheat Flour Producers in 2007, wheat flour consumption in Indonesia reached up to approximately $12 \%$ of the whole food consumption. In 2009 , wheat became the largest imported commodity (4.66 million

Paper was Presented at International Conference on "Future of Food Factors", October 3-4, 2012, Jakarta, Indonesia.

${ }^{*}$ Corresponding Author:

E-mail : ekohari_p@yahoo.com; Phone: +62-251-8624546 tons) (FAO, 2009). The quantity of imported wheat continued to increase in 2011 to 5.49 million tons (BPS, 2011).

One of bakery products traditionally made from wheat is muffin. Muffin is small cup-shaped quick bread that is generally dominated by sweet taste and can be served with meal or consumed as a snack. Muffin is characterized by a typical porous structure and high volume. To obtain such a structure, a stable batter lodging many tiny air bubbles is required (Baixauli et al., 2008). Wheat flour normally used for muffin is moderate to weak flour with $8 \%-10 \%$ protein content. This open the possibility to produce muffins from local flours such as corn and sweet potato which are lacking in gluten.

The introduction of corn and sweet potato flour in muffin production is aimed to support food diversification program and reduce our dependence on wheat flour. Productivity of sweet potato and corn is relatively high. The production of corn in 
Indonesia reaches 18.33 million tons while that of sweet potatoes as much as 2.05 million tons (BPS, 2011). The purpose of this study is to optimize the composite flour composition and baking process condition in muffin production.

\section{MATERIALS AND METHODS}

\section{Materials}

The materials used in muffin making process were 'Segitiga Biru' wheat flour, sweet potato flour (100 mesh), corn flour (100 mesh), margarine, water, salt, eggs, sugar, and baking powder.

\section{Formula optimization}

Formula optimization was initiated by determination of the maximum level of single flour substitution. The range of substitution level tested for corn flour was $50 \%-100 \%$, while for sweet potato flour was 20\%-70\%. Substituted muffins were sensory tested using hedonic rating test to 30 panelists and the data was futher analyzed statistically (ANOVA). The next step after determining the maximum point of single flour substitution was optimization step using mixture design method in Design Expert $7.0^{\circledR}$ software. The range of flours composition (wheat flour, corn flour, and sweet potato flour) was feed to the software to obtain the formula combinations. Each formula obtained from the software was sensory tested using line scale hedonic rating test to 70 untrained panelists. The sensory atribute tested were color, aroma, taste, texture, and overal sensory response of muffin. Responses were then analyzed and optimized to obtain an optimum formula. Finally, optimum formula was verified to check the agreement between the actual and predicted response. Flow diagram of muffin production is shown in Figure 1. Formula optimization was based on basic recipe which is shown in Table 1 . Level of corn and sweet potato flour was calculated relative to total flour used.

Table 1. Muffin basic formula

\begin{tabular}{lc}
\hline \multicolumn{1}{c}{ Ingredients } & Amount (g) \\
\hline Wheat flour & 525 \\
Eggs & 300 \\
Margarine & 345 \\
Salt & 3 \\
Water & 165 \\
Refined sugar & 320 \\
Baking powder & 7.5 \\
\hline
\end{tabular}

\section{Process optimization}

Process optimization was conducted using response surface method in Design Expert $7.0^{\circledR}$ software. The range of baking parameters (time and temperature) were feed into the software to obtain different combinations of baking time and temperature. Each process was sensory tested using line scale hedonic rating test to 70 untrained panelists. The sensory atribute tested were color, aroma, taste, texture, and overall response of muffin. Responses were then analyzed and optimized to obtain an optimum process. Finally, optimum process was verified to check the agreement between the actual and predicted responses.

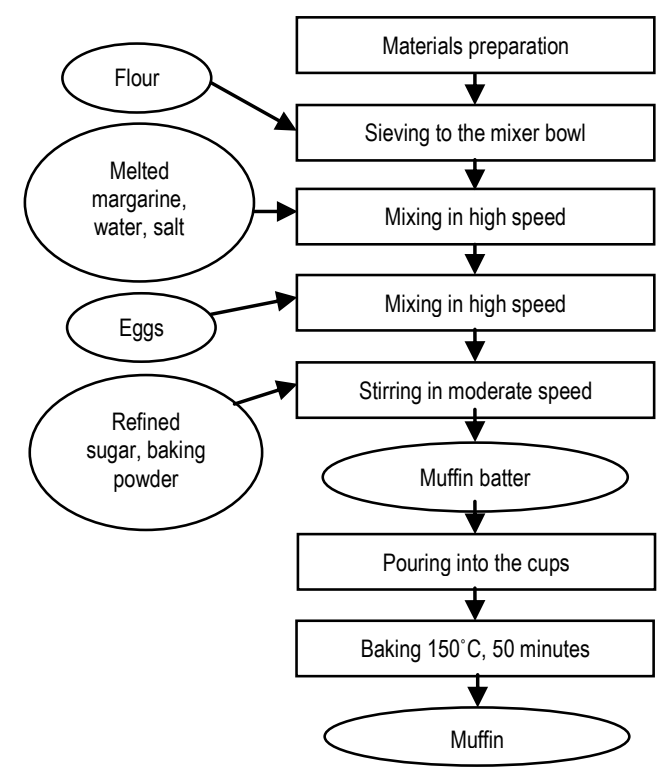

Figure 1. Flow diagram of muffin production

\section{Hardness analysis of final product}

Texture of muffin was measured using Texture Analyzer Stable Micro System TA-XT2. Probe specification and setting is shown in Table 2.

Table 2. Probe specification and texture analyzer setting for muffin

\begin{tabular}{ll}
\hline \multicolumn{1}{c}{ Specification } & \\
\hline Type & TA-XT2 \\
Mode & Measure force in compression \\
Option & Return to Start \\
Pre-test speed & $2.0 \mathrm{~mm} / \mathrm{s}$ \\
Test speed & $0.5 \mathrm{~mm} / \mathrm{s}$ \\
Post-test speed & $10.0 \mathrm{~mm} / \mathrm{s}$ \\
Distance & $10 \mathrm{~mm}$ \\
Trigger type & Auto $-5 \mathrm{~g}$ \\
Data acquistion rate & $200 \mathrm{pps}$ \\
\hline
\end{tabular}

\section{Proximate analysis of final product}

Proximate analysis consists of moisture content analysis using oven evaporation method (Indonesian National Standard (SNI) 01-2891-1992), ash content analysis using dry ashing method (SNI 01-2891-1992), protein content analysis using Kjeldahl method (AOAC, 1995), fat content analysis using Soxhlet method (SNI 01-2891-1992), carbohydrate content analysis using by difference method (Nielsen, 2010), and crude fiber content analysis using gravimetric method (Nielsen, 2010).

\section{RESULTS AND DISCUSSION}

\section{Formula optimization}

Sensory responses on the muffin produced from corn flour substitution is presented in Table 3 .

Duncan test on the panelist acceptance of corn substituted muffin indicates that the maximum point of substitution was $100 \%$. This was because the panelists' hedonic score for all sensory attributes at substitution level from $50 \%$ to $100 \%$ was 
not significantly different at $5 \%$ significance level. In addition, the average hedonic score for overall attribute at $100 \%$ substitution level was equal to 6.69 , which means that the muffin was preferred by panelists.

Table 3. Panelist acceptance of corn substituted-muffin

\begin{tabular}{lcccccc}
\hline \multirow{2}{*}{ Parameter } & \multicolumn{5}{c}{ Hedonic Score of Muffin at Different Level of Corn } \\
\cline { 2 - 7 } & $50 \%$ & $60 \%$ & $70 \%$ & $80 \%$ & $90 \%$ & $100 \%$ \\
\hline Color & $6.8^{\mathrm{a}}$ & $6.6^{\mathrm{a}}$ & $6.8^{\mathrm{a}}$ & $7.2^{\mathrm{a}}$ & $7.1^{\mathrm{a}}$ & $7.3^{\mathrm{a}}$ \\
Aroma & $5.8^{\mathrm{a}}$ & $6.0^{\mathrm{a}}$ & $5.8^{\mathrm{a}}$ & $6.2^{\mathrm{a}}$ & $6.5^{\mathrm{a}}$ & $6.9^{\mathrm{a}}$ \\
Taste & $6.2^{\mathrm{a}}$ & $6.2^{\mathrm{a}}$ & $6.0^{\mathrm{a}}$ & $6.1^{\mathrm{a}}$ & $6.4^{\mathrm{a}}$ & $6.7^{\mathrm{a}}$ \\
Texture & $5.3^{\mathrm{a}}$ & $5.3^{\mathrm{a}}$ & $5.6^{\mathrm{a}}$ & $5.9^{\mathrm{a}}$ & $5.9^{\mathrm{a}}$ & $5.6^{\mathrm{a}}$ \\
Over all & $6.5^{\mathrm{a}}$ & $6.3^{\mathrm{a}}$ & $6.2^{\mathrm{a}}$ & $6.3^{\mathrm{a}}$ & $6.6^{\mathrm{a}}$ & $6.7^{\mathrm{a}}$ \\
\hline
\end{tabular}

Note: the same superscript indicates no significance difference at significance level of $5 \%$

The characteristics of $100 \%$ corn flour-muffin were yellow in color, slightly less compact texture, strong corn aroma, uniform cells structure and moderate in size (similar to $100 \%$ wheat flour-muffin), and well developed. The $100 \%$ corn flour-muffins are shown in Figure $6 a$.

Sensory responses on muffin produced from sweet potato flour substition is shown in Table 4. Duncan test on hedonic score of sweet potato flour substituted muffin showed that the maximum point of substitution was $40 \%$. This was because the hedonic score for the substitution level of $50 \%$ to $70 \%$ is less than 5 (dislike).

Table 4. Panelist acceptance of sweet potato flour substituted-muffin

\begin{tabular}{lcccccc}
\hline \multirow{2}{*}{ Parameter } & \multicolumn{5}{c}{ Hedonic Score of Muffin at Different Level of Sweet } \\
\cline { 2 - 7 } & $20 \%$ & $30 \%$ & $40 \%$ & $50 \%$ & $60 \%$ & $70 \%$ \\
\hline Color & $6.5^{\mathrm{a}}$ & $6.0^{\mathrm{ab}}$ & $5.8^{\mathrm{ab}}$ & $5.5^{\mathrm{ab}}$ & $5.1^{\mathrm{b}}$ & $5.4^{\mathrm{ab}}$ \\
Aroma & $6.1^{\mathrm{a}}$ & $5.6^{\mathrm{ab}}$ & $5.6^{\mathrm{ab}}$ & $4.9^{\mathrm{abc}}$ & $4.8^{\mathrm{c}}$ & $4.4^{\mathrm{c}}$ \\
Taste & $6.0^{\mathrm{a}}$ & $6.1^{\mathrm{a}}$ & $5.9^{\mathrm{a}}$ & $4.9^{\mathrm{b}}$ & $4.5^{\mathrm{b}}$ & $4.4^{\mathrm{b}}$ \\
Texture & $6.2^{\mathrm{a}}$ & $5.4^{\mathrm{a}}$ & $5.3^{\mathrm{a}}$ & $4.3^{\mathrm{b}}$ & $4.0^{\mathrm{b}}$ & $3.7^{\mathrm{b}}$ \\
Over all & $6.4^{\mathrm{a}}$ & $6.0^{\mathrm{a}}$ & $6.1^{\mathrm{a}}$ & $4.9^{\mathrm{b}}$ & $4.4^{\mathrm{b}}$ & $4.3^{\mathrm{b}}$ \\
\hline
\end{tabular}

Note: the same superscript indicates no significance difference at significance level of $5 \%$

The characteristics of $40 \%$ sweet potato flour substituted muffin were dark brown in color, compact and sticky texture, strong sweet potato aroma, and not well developed. The $40 \%$ sweet potato flour substituted muffins are shown in Figure $6 \mathrm{~b}$. The texture of sweet potato flour substituted muffin was less preferred by panelists due to its slightly sticky texture. The sticky texture of the product is due to high viscosity of sweet potato flour dough (480 BU) (ljarotimi and Ashipa, 2005). Viscosity of wheat flour and corn flour dough are $430 \mathrm{BU}$ (Oladunmoye et al., 2010) and 154.46 BU (Phattanakulkaewmorie, 2011) respectively. Dough with lower viscosity exhibited more compact texture of muffin than sweet potato flour substituted muffin, thus more preferred by the panelists. Based on the maximum level of single flour substitution, the percentage of wheat, corn, and sweet potato flour feed into the mixture design software were 0 $20 \%, 60-90 \%$, and $10-40 \%$, respectively. The maximum point of corn flour used in the design was $90 \%$ to retain the use of sweet potato flour in formula.
All of the formula combinations were tested and the response values obtained are shown in Table 5. Hedonic score of 1 corresponded to extremely dislike response whereas hedonic score of 10 indicated extremely like response with score of 5 indicated neither like nor dislike response. The panelist response was further used to developed models to describe the response and shown in Table 6.

Table 5. Hedonic response of muffin produced from different flour compositions

\begin{tabular}{cccccccc}
\hline \multicolumn{3}{c}{ Flour Composition (\%) } & \multicolumn{5}{c}{ Hedonic Score } \\
\hline WF $^{*}$ & CF* $^{*}$ & SPF* & Color & Aroma & Taste & Texture & $\begin{array}{c}\text { Over } \\
\text { all }\end{array}$ \\
\hline 0 & 75 & 25 & 6.2 & 5.5 & 5.2 & 4.7 & 5.4 \\
0 & 90 & 10 & 6.7 & 5.8 & 5.8 & 5.1 & 6 \\
0 & 75 & 25 & 6 & 5.6 & 5.5 & 5.1 & 5.8 \\
11 & 60 & 29 & 4.3 & 5.2 & 5.2 & 5.1 & 5.3 \\
20 & 60 & 20 & 6.7 & 6 & 5.4 & 4.6 & 5.7 \\
4.4 & 67 & 28.5 & 5.7 & 5.8 & 5.4 & 4.5 & 5.4 \\
20 & 66.7 & 13.3 & 6.2 & 5.4 & 5.2 & 4.6 & 5.5 \\
0 & 90 & 10 & 6.7 & 5.7 & 5.5 & 5.4 & 6 \\
5.5 & 79.6 & 14.9 & 6.4 & 6.2 & 5.9 & 5.7 & 6 \\
10.3 & 69.3 & 20.4 & 5.1 & 5.6 & 5.6 & 5.3 & 5.6 \\
15.6 & 74.4 & 10 & 6.9 & 6 & 5.6 & 5.3 & 6.1 \\
20 & 60 & 20 & 6.3 & 6.1 & 6 & 5.4 & 6.3 \\
0 & 60 & 40 & 3.9 & 5 & 5.1 & 4.2 & 5.1 \\
15.6 & 74.4 & 10 & 7 & 5.6 & 6 & 4.9 & 6 \\
5.2 & 60.6 & 34.2 & 4.8 & 5 & 5.1 & 4.1 & 5 \\
0 & 60 & 40 & 3.7 & 4.9 & 5.1 & 4.3 & 4.7 \\
\hline
\end{tabular}

Note: *WF: wheat flour; CF: corn flour ; SPF: sweet potato flour

Each sensory parameter was satisfactorily described using different polynomial models. Based on the $p$-value, all the parameters had significant model $(p<0.05)$ and not significant lack of fit $(p>0.05)$. This indicates that the model appropriately describe the hedonic response. Adjusted $R^{2}$ is a measure of the amount of variation about the mean explained by the model while Predicted $\mathrm{R}^{2}$ represented the amount of variation in new data explained by the model. Value of 1.0 for Adjusted $R^{2}$ and Predicted $\mathrm{R}^{2}$ showed the ideal condition in which $100 \%$ of the variation in the observed values could be represented by the chosen model. Adequate precision is a measure of the range in predicted response relative to its associated error, in other words a signal to noise ratio. Its desired value is 4 or more.

All parameters had adequate precision greater than 4 . The positive constant in the equation showed that the hedonic score would increase with an increase in the number of components or interactions between components. Increased amount of sweet potato flour resulted in dark brown color muffin and lower hedonic score. Crust browning is associated with caramelization and Maillard reactions between protein and reducing sugars (Purlis and Salvadori, 2009). High sugar content in sweet potato flour, amounting to $12.7-12.9 \%$ (w.b) (Brinley et al., 2008, Nabubuya et al., 2012), induces Maillard reaction intensively. Increased amount of sweet potato flour also caused strong sweet potato aroma and lower hedonic scores for aroma attribute. Higher amount of sweet potato flour produced high viscosity batter and give sticky texture to the final product. 
Table 6. Mathematical model to describe hedonic response at formula optimization step

\begin{tabular}{|c|c|c|c|c|c|c|c|}
\hline \multirow{2}{*}{ Parameter } & \multirow{2}{*}{$\begin{array}{l}\text { Model } \\
\text { Orde }\end{array}$} & \multicolumn{2}{|c|}{$p$-Value } & \multirow{2}{*}{$\begin{array}{c}\text { Adjusted } \\
\mathrm{R}^{2}\end{array}$} & \multirow{2}{*}{$\begin{array}{c}\text { Predicted } \\
\mathrm{R}^{2}\end{array}$} & \multirow{2}{*}{$\begin{array}{l}\text { Adequate } \\
\text { Precision }\end{array}$} & \multirow{2}{*}{ Equations } \\
\hline & & Model & Lack of Fit & & & & \\
\hline Color & $\begin{array}{c}\text { Reduced } \\
\text { cubic }\end{array}$ & $\begin{array}{c}<0.0001 \\
\text { (sig) }\end{array}$ & $\begin{array}{l}0.1155 \\
\text { (n sig) }\end{array}$ & 0.9705 & 0.874 & $\begin{array}{l}22.156 \\
(>4.0)\end{array}$ & $\begin{array}{l}\text { Color }=12.31 \mathrm{~A}+0.16 \mathrm{~B}-4.25 \mathrm{C}-0.21 \mathrm{AB}-0.07 \mathrm{AC}+0.07 \mathrm{BC} \\
-1.01 \times 10^{-3} \mathrm{AB}(\mathrm{A}-\mathrm{B})-\left(5.35 \times 10^{-4}\right) \mathrm{AC}(\mathrm{A}-\mathrm{C})-\left(4.97 \times 10^{-4}\right) \\
\mathrm{BC}(\mathrm{B}-\mathrm{C})\end{array}$ \\
\hline Aroma & Cubic & $\begin{array}{c}0.0048 \\
\text { (sig) }\end{array}$ & $\begin{array}{l}0.9461 \\
\text { (n sig) }\end{array}$ & 0.8516 & 0.7628 & $\begin{array}{l}10.152 \\
(>4.0)\end{array}$ & $\begin{array}{l}\text { Aroma }=5.91 A+0.1 B-1.96 C-0.11 A B-0.04 A C+0.04 B C+ \\
2.3 \times 10-4 A B C-5.48 \times 10-4 A B(A-B)-1.5 \times 10-5 A C(A-C)- \\
2.4 \times 10-4 B C(B-C)\end{array}$ \\
\hline Taste & Linear & $\begin{array}{c}0.0214 \\
\text { (sig) }\end{array}$ & $\begin{array}{l}0.6125 \\
\text { (n sig) }\end{array}$ & 0.3612 & 0.1342 & $\begin{array}{l}5.673 \\
(>4.0)\end{array}$ & Taste $=0.06 \mathrm{~A}+0.06 \mathrm{~B}+0.04 \mathrm{C}$ \\
\hline Texture & Linear & $\begin{array}{c}0.0135 \\
\text { (sig) }\end{array}$ & $\begin{array}{l}0.3517 \\
\text { (n sig) }\end{array}$ & 0.4035 & 0.2405 & $\begin{array}{l}5.673 \\
(>4.0)\end{array}$ & Texture $=0.05 \mathrm{~A}+0.06 \mathrm{~B}+0.02 \mathrm{C}$ \\
\hline Overall & Linear & $\begin{array}{c}0.0002 \\
\text { (sig) }\end{array}$ & $\begin{array}{l}0.6151 \\
\text { (n sig) }\end{array}$ & 0.6848 & 0.5669 & $\begin{array}{l}10.259 \\
(>4.0)\end{array}$ & Overall $=0.07 \mathrm{~A}+0.06 \mathrm{~B}+0.03 \mathrm{C}$ \\
\hline
\end{tabular}

Note: $\mathrm{A}=$ wheat flour $(\%), \mathrm{B}=$ corn flour $(\%), \mathrm{C}=$ sweet potato flour $(\%)$, sig $=$ significant $(\alpha=0.05), \mathrm{n}$ sig $=$ not significant $(\alpha=0.05)$

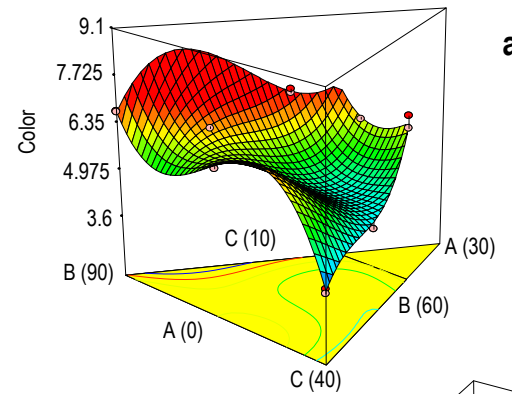

a

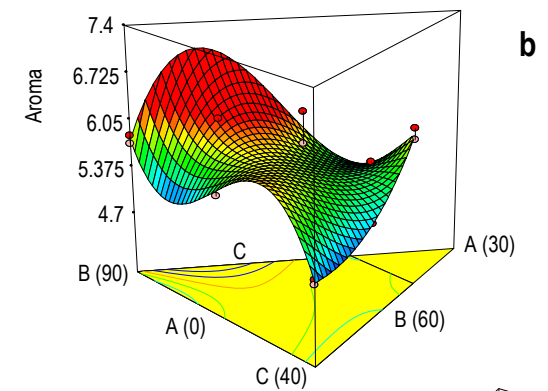

b

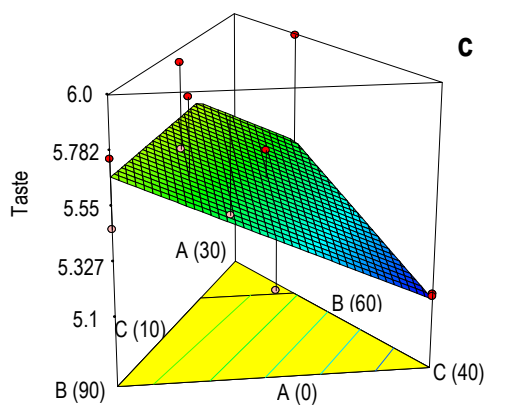

d

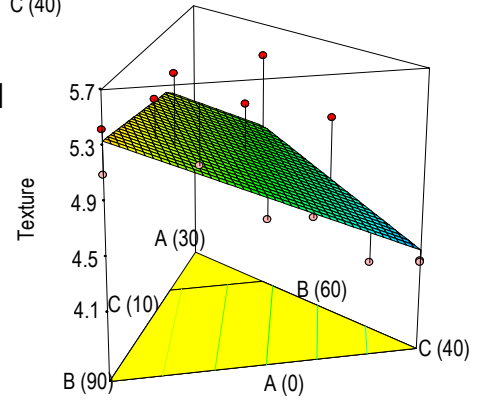

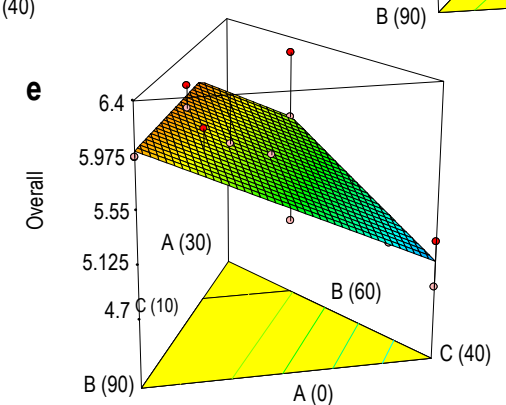

Figure 2. Three-dimensional graphs in formula optimization for (a) color (b) aroma (c) taste (d) texture and (e) overall responses

The high viscosity in sweet potato flour was due to a high swelling ability by its high starch content $(65.5 \%)$ and low protein content (3.15\%) so that the starch granules are easier to expand and absorb water (Aprianita et al., 2009). Three-dimensional graphs of sensory responses (color, aroma, taste, texture, and overall) in formula optimization step are shown in Figure 2. Sensory responses were then optimized by determining desired goal and importance level of the variable as indicated in Table 7. Optimum formula obtained from optimization of sensory responses was $4 \%$ wheat flour, $86 \%$ corn flour, and $10 \%$ sweet potato flour.

Table 7. Goal and importance criteria of each variable in formula optimization

\begin{tabular}{lcccc}
\hline \multicolumn{1}{c}{ Variable } & Goal & Lower & Upper & Importance \\
\hline WF $^{*}$ & In range & 0 & 20 & \\
CF $^{*}$ & In range & 60 & 90 & \\
SPF $^{*}$ & In range & 10 & 40 & \\
Color & Maximize & 3.74 & 7.01 & ${ }^{+++++}$ \\
Aroma & Maximize & 4.91 & 6.19 & ${ }^{+++++}$ \\
Taste & Maximize & 5.11 & 6.00 & ${ }^{+++++}$ \\
Texture & Maximize & 4.12 & 5.66 & +++++ \\
Overall & Maximize & 4.74 & 6.27 & ${ }^{+++++}$ \\
\hline
\end{tabular}

Note: *WF: wheat flour; CF: corn flour; SPF: sweet potato flour
Desirability value of optimum formula was 0.844 . The higher desirability value indicated the high suitability of formula to achieve the desired response. Characteristics of muffin obtained from formula optimization (Figure 6c) were dark yellow, slightly less compact texture, strong corn aroma, moderate size cells, and high volume development. Three-dimensional graph of the optimum formula is presented in Figure 3.

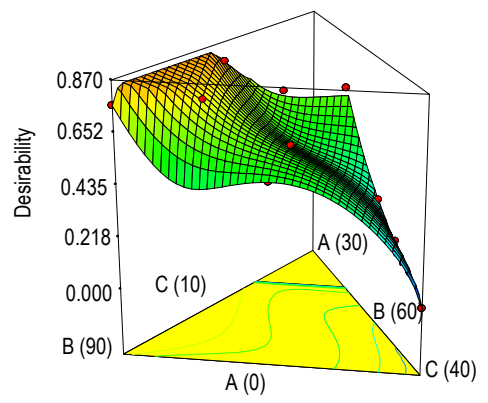

Figure 3. Three-dimensional graph of the optimum formula

The formula was then verified to prove the conformity between the actual response and the predicted response value. Conformity was indicated by the sensory response of verification process which is within the range Confident Interval $(\mathrm{Cl})$ or a 
Prediction Interval (PI). Confident interval is a range that shows the expectation of the average results from subsequent measurements on a particular significance level, in this case $5 \%$. Prediction interval is a range that shows the expectation of results from subsequent measurements. Table 8 shows the verification results of the optimum formula.

Table 8. Comparison of predicted and measured sensory response obtained from verification process

\begin{tabular}{lcccccc}
\hline & \multicolumn{3}{c}{ Sensory Response } & \multicolumn{5}{c}{ Sensory } \\
\cline { 2 - 7 } Parameter & Predictional & Verification & $\begin{array}{c}95 \% \\
\mathrm{Cl} \\
\text { Low }\end{array}$ & $\begin{array}{c}95 \% \\
\mathrm{Cl} \\
\text { High }\end{array}$ & $\begin{array}{c}95 \% \\
\mathrm{Pl} \\
\text { Low }\end{array}$ & $\begin{array}{c}95 \% \\
\text { PI }\end{array}$ \\
\hline Color & 8.25 & 7.61 & 7.57 & 8.94 & 7.44 & 9.07 \\
Aroma & 6.91 & 6.39 & 6.30 & 7.51 & 6.19 & 7.62 \\
Taste & 5.69 & 6.21 & 5.44 & 5.94 & 5.10 & 6.29 \\
Texture & 5.32 & 5.62 & 4.95 & 5.69 & 4.45 & 6.19 \\
Overall & 6.04 & 6.23 & 5.79 & 6.29 & 5.44 & 6.63 \\
\hline
\end{tabular}

Verification result showed that the value for the response of color, aroma, texture, and overall was in the 95\% Confident Interval. The response of taste was within the 95\% Prediction Interval. Verification of sensory response was close to the predicted value. Therefore, it could be concluded that the models are suitable to determine the optimum formula within the studied range.

\section{Process optimization}

Process optimization was carried out using response surface experimental design which was available in the Design Expert $7.0 @$ software. The optimized variables were baking temperature and time. Minimum and maximum point of baking time and temperature feed into the software is shown in Table 9.

Table 9. The range of baking time and temperature

\begin{tabular}{ccccc}
\hline Variable & -1 Level & +1 Llevel & -Alpha & +Alpha \\
\hline Temp. $\left({ }^{\circ} \mathrm{C}\right)$ & 150 & 170 & 145.86 & 174.14 \\
Time $(\mathrm{min})$ & 25 & 50 & 19.82 & 55.18 \\
\hline
\end{tabular}

The combinations of baking temperature and time suggested by the software are shown in Table 10. Muffin produced using optimum formula was then baked under different baking condition as suggested by the software. Table 10 also shows the sensory responses of the muffin obtained from 70 untrained panelists. The models developed based on the sensory responses are shown in Table 11. Based on the results obtained, only the overall response had a significant lack of fit. This could becaused by the large standard deviation of the data. More over, the value of Predicted $\mathrm{R}^{2}$ for overall parameter was negative which indicated that the overall mean was a better predictor than the model. Nevertheless, it still has a significant model so that the overall parameter is still eligible to be included in the optimization stage. Three-dimensional graphs in formula optimization for each parameter is shown in Figure 4.

Table 10. Hedonic response of muffin produced from different baking temperature and time

\begin{tabular}{ccccccc}
\hline $\begin{array}{c}\text { Temp. } \\
\left({ }^{\circ} \mathrm{C}\right)\end{array}$ & $\begin{array}{c}\text { Time } \\
\text { (min.) }\end{array}$ & Color & Aroma & Taste & Texture & $\begin{array}{c}\text { Over } \\
\text { all }\end{array}$ \\
\hline 160 & 38 & 6.6 & 6.2 & 5.9 & 5.3 & 6.1 \\
170 & 25 & 3.5 & 4.5 & 5.0 & 5.2 & 4.5 \\
160 & 38 & 6.4 & 6.1 & 6 & 5.5 & 6.1 \\
150 & 50 & 6.1 & 6 & 6.0 & 5.2 & 5.8 \\
170 & 50 & 3.1 & 3.9 & 4 & 3.6 & 3.6 \\
160 & 38 & 6.2 & 6.3 & 5.9 & 5.5 & 6.0 \\
150 & 25 & 4.7 & 5.3 & 5.0 & 4.1 & 4.7 \\
146 & 38 & 4.9 & 5.2 & 5.5 & 4.9 & 5.3 \\
174 & 38 & 4.8 & 5.1 & 5.8 & 5.2 & 5.6 \\
160 & 55 & 4.6 & 5.1 & 5.2 & 4.7 & 5.1 \\
160 & 38 & 6.4 & 5.9 & 6.1 & 5.7 & 6.2 \\
160 & 20 & 4.6 & 4.9 & 4.8 & 4.0 & 4.6 \\
160 & 38 & 6.2 & 6.0 & 6.2 & 5.6 & 6.2 \\
\hline
\end{tabular}

Sensory response optimization resulted in an optimum baking process condition at $158^{\circ} \mathrm{C}$ for 39 minutes with desirability value of 0.979 . Baking time was around $20 \%$ shorter than the baking time of muffins before optimization. Such a reduction in baking time is very important in increasing through put during full production in a factory. The hedonic scores for all parameter were more than 5 meaning that the product was desirable and acceptable by panelists.

Desirability value of 0.979 was considered as high for a new product. Compared to the characteristics of the $100 \%$ wheat flour-muffin, muffin obtained from the baking process optimization (Figure 6d) had brown color, crumbly and dry texture, and the volume development was not as high as the $100 \%$ wheat flour-muffin. The brown color of substituted muffin occurred was due to the natural colour of sweet potato flour. Crumbly texture and the development of lower volume was caused by the low content of gluten in the batter that needed to form structure and trap air bubbles. Three-dimensional graphs of the process optimization is presented in Figure 5.

The advantages of using composite flour in muffin is to diversify the use of local carbohydrate resources. The combination of sweet potato flour, corn flour and wheat flour could also increase certain nutritional content of the final product. Beta-carotene content of sweet potato (2300 $\mathrm{mkg} / 100 \mathrm{~g}$, Teow et al., 2006) is much higher than corn (29 $\mathrm{mkg} / 100 \mathrm{~g}$, Perry et al., 2009) so that it is expected to increase the presence of beta-carotene on the final product. However, beta-carotene is unstable to heat. Nevertheless, high retention of beta-carotene was ever observed in oven drying that reached 89\%-96\% (Vimala et al., 2011), whereas retention by baking was up to $43.17 \%$ (Inocent et al., 2011). High intake of betacarotene may help protect against oxidative damage, thus lowering cancer and cardiovascular disease risk (Genkinger et al., 2004). These four types of muffins are shown in Figure 6. 
Versi Online:

http://journal.ipb.ac.id/index.php/jtip

DOI: 10.6066/jtip.2012.23.2.165

Hasil Penelitian

J. Teknol dan Industri Pangan, Vol. XXIII No. 2 Th. 2012

Table 11. Mathematical model to describe hedonic response at baking optimization step

\begin{tabular}{|c|c|c|c|c|c|c|c|}
\hline \multirow{2}{*}{ Parameter } & \multirow{2}{*}{ Model Orde } & \multicolumn{2}{|c|}{$\mathrm{p}$-value } & \multirow{2}{*}{$\begin{array}{c}\text { Adjusted } \\
\mathrm{R}^{2}\end{array}$} & \multirow{2}{*}{$\begin{array}{c}\text { Predicted } \\
\mathrm{R}^{2}\end{array}$} & \multirow{2}{*}{$\begin{array}{l}\text { Adequate } \\
\text { Precision }\end{array}$} & \multirow{2}{*}{ Equations } \\
\hline & & Model & Lack of Fit & & & & \\
\hline Color & $\begin{array}{l}\text { Reduced } \\
\text { cubic }\end{array}$ & $\begin{array}{c}0.0004 \\
\text { (sig) }\end{array}$ & $\begin{array}{l}0.0661 \\
\text { (n sig) }\end{array}$ & 0.9313 & 0.4295 & $\begin{array}{l}14.323 \\
(>4.0)\end{array}$ & $\begin{array}{l}\text { Color }=6.39-0.053 \mathrm{~A}+0.12 \mathrm{~B}-0.45 \mathrm{AB}-0.86 \mathrm{~A}^{2}- \\
0.98 \mathrm{~B}^{2}-0.98 \mathrm{AB}^{2}\end{array}$ \\
\hline Aroma & $\begin{array}{l}\text { Reduced } \\
\text { cubic }\end{array}$ & $\begin{array}{l}<0.0001 \\
\text { (sig) }\end{array}$ & $\begin{array}{l}0.3773 \\
\text { (n sig) }\end{array}$ & 0.9518 & 0.7594 & $\begin{array}{l}19.747 \\
(>4.0)\end{array}$ & $\begin{array}{l}\text { Aroma }=6.07-1.41 \mathrm{~A}-0.34 \mathrm{AB}-0.49 \mathrm{~A}^{2}-0.58 \mathrm{~B}^{2}+ \\
\quad 0.69 \mathrm{~A}^{3}\end{array}$ \\
\hline Taste & $\begin{array}{l}\text { Reduced } \\
\text { cubic }\end{array}$ & $\begin{array}{c}0.0028 \\
\text { (sig) }\end{array}$ & $\begin{array}{l}0.0543 \\
\text { (n sig) }\end{array}$ & 0.8646 & 0.2926 & $\begin{array}{l}11.570 \\
(>4.0)\end{array}$ & $\begin{array}{l}\text { Taste }=6.03+0.11 A+0.073 B-0.52 A B-0.27 A^{2}- \\
0.59 B^{2}-0.63 A B^{2}\end{array}$ \\
\hline Texture & $\begin{array}{l}\text { Reduced } \\
\text { quadratic }\end{array}$ & $\begin{array}{l}<0.0001 \\
\text { (sig) }\end{array}$ & $\begin{array}{l}0.0771 \\
\text { (n sig) }\end{array}$ & 0.8651 & 0.7554 & $\begin{array}{l}11.541 \\
(>4.0)\end{array}$ & Texture $=5.52-0.66 \mathrm{AB}-0.28 \mathrm{~A}^{2}-0.64 \mathrm{~B}^{2}$ \\
\hline Overall & Quadratic & $\begin{array}{l}0.0168 \\
\text { (sig) }\end{array}$ & $\begin{array}{l}<0.0001 \\
(\mathrm{sig})\end{array}$ & 0.6825 & -0.2972 & $\begin{array}{l}5.840 \\
(>4.0)\end{array}$ & $\begin{array}{l}\text { Overall }=6.11-0.23 \mathrm{~A}+0.13 \mathrm{~B}-0.52 \mathrm{AB}-0.45 \mathrm{~A}^{2}- \\
\quad 0.76 \mathrm{~B}^{2}\end{array}$ \\
\hline
\end{tabular}

Note: $\mathrm{A}=$ wheat flour $(\%) \mathrm{B}=$ corn flour $(\%) \mathrm{C}=$ sweet potato flour $(\%), \operatorname{sig}=$ significant $(\alpha=0.05), \mathrm{n}$ sig = not significant $(\alpha=0.05)$
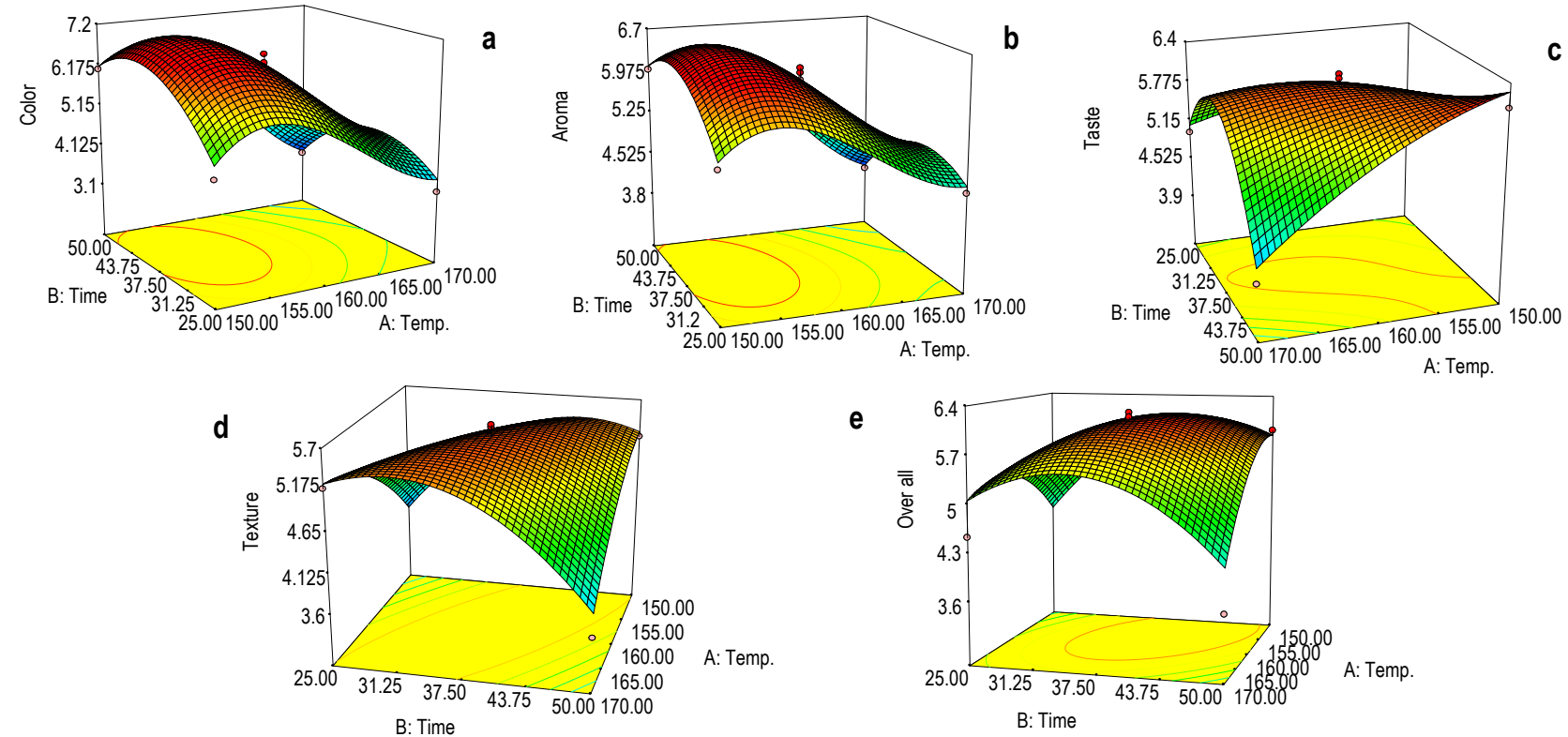

Figure 4. Three-dimensional graphs in process optimization for (a) color (b) aroma (c) taste (d) texture and (e) overall responses

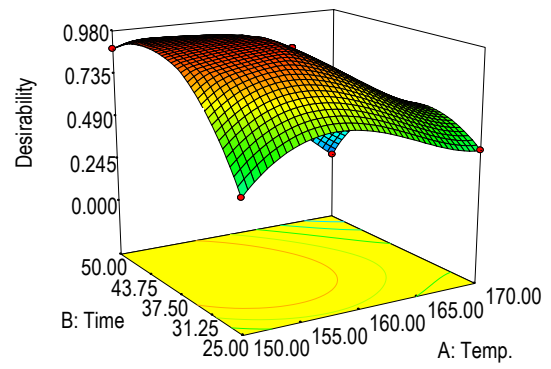

Figure 5. Three-dimensional graphs of the process optimization

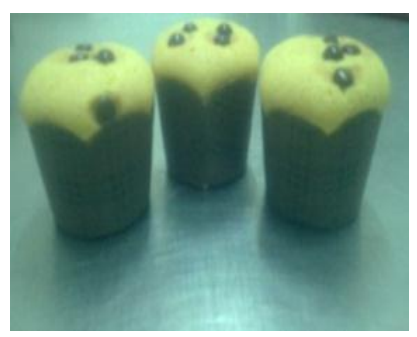

a

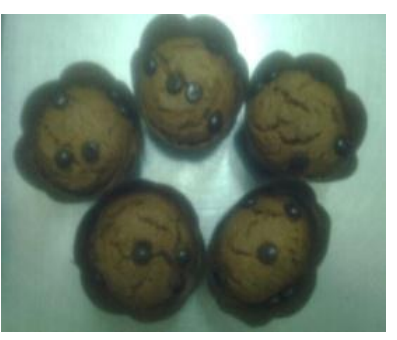

b

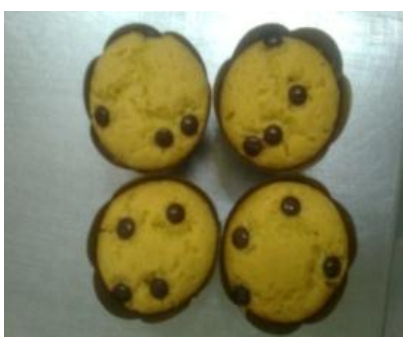

c

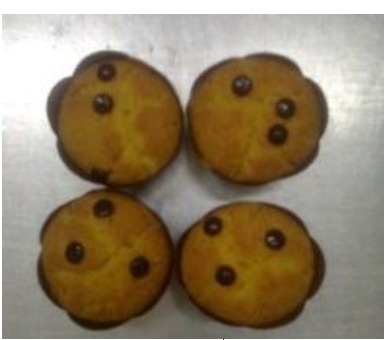

d

Figure 6. (a) $100 \%$ corn flour-muffin (b) $40 \%$ sweet potato substituted-muffin(c) Muffin made from optimum formula (d) Muffin made from optimum formula and process 
Table 13 shows the comparison between the predicted and measured sensory responeses of muffin obtained from process optimization. Based on the verification result (actual response) the value for the response of color, aroma, texture, and overall were still within $95 \%$ Confident interval (in the range of $95 \% \mathrm{Cl}$ low and $95 \% \mathrm{Cl}$ high). For the taste response, even though the value was not in the range, the result of verification provided a better value as compared to the predicted value (above the maximum range). Verification result value was in agreement with the predicted value. Therefore, it was concluded that the model obtained was suitable to determine the optimum process condition.

Table 13. Comparison of predicted and measured sensory response obtained from verification of baking process

\begin{tabular}{|c|c|c|c|c|c|c|}
\hline \multirow[b]{2}{*}{ Parameter } & \multicolumn{2}{|c|}{ Sensory Response } & \multicolumn{4}{|c|}{ Sensory Interval } \\
\hline & $\begin{array}{l}\text { Pre- } \\
\text { diction }\end{array}$ & $\begin{array}{l}\text { Veri- } \\
\text { fication }\end{array}$ & $\begin{array}{c}95 \% \\
\mathrm{Cl} \\
\text { Low }\end{array}$ & $\begin{array}{c}95 \% \\
\mathrm{Cl} \\
\text { High }\end{array}$ & $\begin{array}{c}95 \% \\
\mathrm{Pl} \\
\text { Low }\end{array}$ & $\begin{array}{c}95 \% \\
\mathrm{Pl} \\
\text { High }\end{array}$ \\
\hline Color & 6.88 & 6.62 & 6.49 & 7.27 & 6.03 & 7.72 \\
\hline Aroma & 6.41 & 6.58 & 6.22 & 6.61 & 5.99 & 6.84 \\
\hline Taste & 6.34 & 7.27 & 6.02 & 6.65 & 5.66 & 7.02 \\
\hline Texture & 5.51 & 5.67 & 5.27 & 5.75 & 4.91 & 6.11 \\
\hline Overall & 6.16 & 6.51 & 5.68 & 6.64 & 4.97 & 7.35 \\
\hline
\end{tabular}

\section{Texture of final product}

Average force measured to deform the sample up to $1.8 \mathrm{~mm}$ is $107.3 \mathrm{gf}$. The greater force required to deform the sample indicates that the sample is harder. Chung et al. (2010) reported that $100 \%$ wheat flour-muffin has hardness value of $290 \mathrm{gf}$. The hardness of composite flour muffin was smaller than the $100 \%$ wheat flour-muffin. It means that the composite flour substitutedmuffin has softer texture than $100 \%$ wheat flour-muffin. Texture analysis results is shown in Table 14.

Table 14. Texture analysis result of composite flour substituted-muffin

\begin{tabular}{cccc}
\hline Sample & Force $(\mathrm{gf})$ & Time $(\mathrm{s})$ & Distance $(\mathrm{mm})$ \\
\hline 1 & 111.8 & 3.605 & 1.800 \\
2 & 113.1 & 3.605 & 1.803 \\
3 & 92.8 & 3.605 & 1.800 \\
4 & 111.5 & 3.605 & 1.803 \\
\hline
\end{tabular}

\section{Proximate composition of final product}

The proximate composition of the composite flour substituteed-muffin is presented in Table 15. Muffin had $18.84 \%$ moisture content. The moisture content of substituted baking product was lower than $100 \%$ wheat flour baking product which ranging from 35.3-36.5\% (Barcenas and Rosell, 2006).

Table 15. Proximate analysis result of composite flour substitutedmuffin

\begin{tabular}{cc}
\hline Analysis & Wet Based (\%) \\
\hline Moisture & 18.84 \\
Ash & 1.48 \\
Protein & 4.78 \\
Fat & 18.23 \\
Carbohydrate & 56.67 \\
Crude fiber & 0.26 \\
\hline
\end{tabular}

The low level of moisture in substituted muffin was due to lower baking temperature and longer baking time as compared to traditional process $\left(200^{\circ} \mathrm{C}\right.$ for 20 minutes). A fairly high fat content $(18.23 \%)$ came from the use of margarine in muffins making process that reached up to $20.71 \%$ of the total ingredients. Carbohydrate content of $56.67 \%$ came from the use of flour which reaches up to $31.52 \%$ of the total ingredients. Substitution of sweet potato also was found to increase ash content in the baking product (Hathorn et al., 2008).

\section{CONCLUSION}

Corn and sweet potato flour could substitute wheat flour in muffins up to $96 \%$ with acceptable sensory properties. Optimum formula of muffin from composite flours was $4 \%$ wheat flour, $86 \%$ corn flour and $10 \%$ sweet potato flour. The results of the process optimization showed that the optimum baking process conditions was at $158^{\circ} \mathrm{C}$ for 39 minutes. The baking time was shorter than the baking time of wheat flour muffin which was 50 minutes. The final product (muffin made from $4 \%$ wheat flour, $86 \%$ corn flour and $10 \%$ sweet potato flour baked at $158^{\circ} \mathrm{C}$ for 39 minutes) had a hardness value of $107.3 \mathrm{gf}$ and contains $18.84 \%$ moisture, $1.48 \%$ ash, $4.78 \%$ protein, $18.23 \%$ fat, $56.67 \%$ carbohydrate, and $0.26 \%$ crude fiber.

\section{ACKNOWLEDGEMENT}

This research is financially supported by PT. Indofood Sukses Makmur through Indofood Riset Nugraha Program.

\section{REFERENCES}

Aprianita A, Purwandari U, Watson B, and Vasiljevic T. 2009. Physico-chemical properties of flours and starches from selected commercial tubers available in Australia. Int Food Res J 16: 507-520.

[AOAC] Association of Official Analytical Chemists. 1995. Official Method of Analysis 960.5, Chapter 12.1.07, pp.7.

[BPS] Badan Pusat Statistik (Statistics Indonesia). 2011. Tabel Impor Menurut Komoditi, Tahun 2011. www.bps.go.id/eximframe.php [April 17th 2012].

Baixauli R, Sanz T, Salvador A, Fiszman SM. 2008. Muffins with resistant starch: Baking performance in relation to the rheological properties of the batter. J Cereal Sci 47: 502209. DOI: 10.1016/j.jcs.2007.06.015.

Barcenas ME, Rosell CM. 2006. Effect of frozen storage time on the bread crumb and aging of parbaked bread. Food Chem 95: 438-445. DOI: 10.1016/i.foodchem.2005.01.023.

Brinley TA, Truong VD, Coronel P, Simunovic J, Sandeep KP. 2008. Dielectric properties of sweet potato purees at 915 $\mathrm{mhz}$ as affected by temperature and chemical composition. Int J Food Prop 11: 158-172. DOl: 10.1080/10942910701284291. 
Chung HJ, Lee SE, Han JA, Lim ST. 2010. Physical properties of dry-heated octenyl succinylated waxy corn starches and its application in fat-reduced muffin. J Cereal Sci 52: 496501. DOI: $10.1016 /$ j.jcs.2010.08.008.

[FAO] Food and Agricultural Organization. 2009. Imports: Commodities by Country. http://faostat.fao.org/site/342/ default.aspx [Auguts 19th 2011].

Genkinger JM, Platz EA, Hoffman SC, Comstock GW, Helzlsouer KJ. 2004. Fruit, vegetable, and antioxidant intake and all-cause, cancer, and cardiovascular disease mortality in a community-dwelling population in Washington County, Maryland. Am J Epidemiol 160: 1223-1233. DOI: 10.1093/aje/kwh339.

Hathorn CS, Biswas MA, Gichuhia PN, Bovell-benjamin AC. 2008. Comparison of chemical, physical, microstructural, and microbial properties of breads supplemented with sweet potato flour and high gluten dough enhancers. LWT Food Sci Technol 41: 803-815. DOI: 10.1016/j.Iwt.2007.06.020.

ljarotimi OS, Ashipa F. 2005. Chemical composition, sensory and physical property of home processed weaning food based on low cost locally available food materials (1). Int J Mol Med 1: 213-219.

Inocent G, Adelaide DM, Giséle EL, Solange MOR, Richard EA, Elie F. 2011. Impact of three cooking methods (steaming, roasting on charcoal and frying) on the beta-carotene and vitamin $\mathrm{C}$ contents of plantation and sweet potato. Am J Food Technol 6: 994-1001. DOl: 10.3923/ajft.2011.994.1001.

Nabubuya A, Namutebi A, Byaruhanga Y, Narvhus J, Wicklund T. 2012. Potential use of selected sweet potato (Ipomea batatas Lam) varieties as defined by chemical and flour pasting characteristics. Food Nutr Sci 3: 889-896. DOl: 10.4236/fns.2012.37118.

Nielsen SS. 2010. Food Analysis. 4th ed. USA: Springer. DOI: 10.1007/978-1-4419-1478-1.

Oladunmoye OO, Akinoso R, Olapade AA. 2010. Evaluation of some physical-chemical properties of wheat, cassava, maize and cowpea flours for bread making. J Food Quality 33: 693-708. DOI: 10.1111/j.1745-4557.2010.00351.x.

Perry A, Rasmussen H, Johnson EJ. 2009. Xanthophyll (lutein, zeaxanthin) content in fruits, vegetables and corn and egg products. J Food Comp Anal 22: 9-15. DOl: 10.1016/.j.jfca.2008.07.006.

Phattanakulkaewmorie N, Paseephol T, Moongngarm A. 2011. Chemical compositions and physicochemical properties of malted sorghum flour and characteristics of gluten free bread. World Academy Sci Eng Technol 81: 454-460.

Purlis E, Salvadori VO. 2009. Modelling the browning of bread during baking. Food Res Int 49: 865-870. DOl: 10.1016/j.foodres.2009.03.007.

Teow CC, Truong V, Mc Feeters RF, Thompson RL, Pecota KV, Yencho GC. 2007. Antioxidant activities, phenolic and betacarotene contents of sweet potato genotypes with varying flesh colours. Food Chem 103: 829-838. DOl : 10.1016/j.foodchem.2006.09.033.

Vimala B, Nambisan B, Hariprakash B. 2011. Retention of carotenoids in orange-fleshed sweet potato during processing. J Food Sci Technol 48: 520-524. DOI: 10.1007/s13197$\underline{011-0323-2 .}$ 